\title{
PENGARUH FALSE MOUNTING TERHADAP KUALITAS SEMEN SAPI LIMOUSIN DAN SIMMENTAL DI BALAI INSEMINASI BUATAN LEMBANG
}

\author{
Yuli Siska Kafiar, Sri Adiani*, Agustinus Lomboan, H.F. N. Lapian \\ Fakultas Peternakan Universitas Sam Ratulangi Manado 95115.
}

\begin{abstract}
ABSTRAK
Tujuan penelitian ini untuk mengetahui sejauh mana pengaruh false mounting terhadap kualitas semen sapi Limosin dan Simental di Balai Inseminasi Buatan Lembang. Penelitian ini menggunakan ternak sapi Limousin dan Simmental yang berumur 5-9 tahun sebanyak 110 ekor yang terdiri dari 55 ekor Sapi Limousin dan 55 ekor Simmental. Penelitian ini menggunakan metode pengamatan secara langsung di Balai Inseminasi Buatan Lembang - Provinsi jawa Barat. Data yang diperoleh berupa hasil pengamatan secara makroskopis dan mikroskopis pada Limousin dan Simmental di antaranya, volume, $\mathrm{pH}$, gerakan massa, motilitas spermatozoa dan kosentrasi spermatozoa. Data dianalisisa secara deskriptif dengan cara menghitung standart deviasi, koefisien dan korelasi uji $\mathrm{T}$. Variabel yang diukur dalam penelitian ini yaitu kualitas semen secara makroskopis dan mikroskopis. Hasil penelitian ini menunjukan bahwa pengaruh false mounting terhadap rata-rata volume semen sapi Limousin dan Simmental sangat baik pada 3,4, 5 kali false mounting tidak berbeda nyata, demikian juga dengan ratarata volume, $\mathrm{pH}$, gerakan massa, motilitas spemetozoa dan konsentrasi spermatozoa tidak berbeda nyata.
\end{abstract}

\footnotetext{
*Korespondensi (Correponding author)

Email: sri_adiani@yahoo.com.
}

Disimpulkan bahwa false mounting pada sapi pejantan Limousin dan Simmental di Balai Inseminasi Buatan Lembang berpengaruh pada kualitas semen makroskopis dan mikroskopis tidak berbeda nyata.

Kata Kunci: False Mounting, Kualitas Semen, Sapi Limousin, Sapi Simmental.

\section{ABSTRACT}

THE EFFECT OF FALSE MOUNTING ON SEMEN QUALITY OF LIMOUSIN AND SIMMENTAL BULL IN LEMBANG ARTIFICAL INSEMINATION CENTER. The purpose of this study was to determine the effect of false mounting on the quality of Limosin and Simental bull semen at the Lembang Artificial Insemination Center. The 55 individu of Limousin and 55 Simmental bull aging 5-9 years old have been used in thos study. The data have been collected directly in the Artificial Insemination Center Lembang - West Java Province. The data obtained in the form of macroscopic and microscopic observations on Limousin and Simmental bull include volume, $\mathrm{pH}$, mass movement, spermatozoa motility and spermatozoa concentration. Data were analyzed descriptively by calculating the standard deviations, correlations coefficients and the $\mathrm{T}$ test. The variables measured in this study were macroscopic and microscopic quality of semen. The results of this study indicate that the effect of false mounting on the average semen volume of Limousin and Simmental bull is maximum at 3, 4, and 5 times false mounting but there was not 
significantly difference between the amount of false mounting, as well as the average volume, $\mathrm{pH}$, mass movement, motility of spemetozoa and concentration spermatozoa are not significantly different. It was concluded that false mounting in Limousin and Simmental bulls in Lembang Artificial Insemination Center had no significantly effect on the quality of macroscopic and microscopic semen.

Keywords: False Mounting, Cement Quality, Limousin Cattle, Simmental Cows.

\section{PENDAHULUAN}

False Mounting adalah jumlah banyaknya pengekangan saat pejantan menaiki teaser untuk menunda ejakulasi, merupakan prosedur penampungan yang umum dilakukan disamping handle (menilai kekerasan otot penis saat ereksi melalui pemegangan dengan tangan petugas), sebelum akhirnya seorang petugas memutuskan untuk segera menampung semen pejantan dengan menggunakan vagina buatan. Diharapkan dengan pengekangan tersebut dapat dihasilkan kualitas semen yang lebih bagus.

Untuk meningkatkan jumlah sperma, peningkatan libido pejantan sewaktu penampungan sperma dapat dilakukan dengan cara mengadakan false mounting, mengganti pemancing, mengubah waktu dan tempat penampungan, mendekatkan pejantan. Suryadi (2008) False mounting pada pejantan beberapa kali bertujuan mendekatkan dan membiarkan pejantan menaiki teaser tanpa ejakulasi selama beberapa menit merupakan cara yang efektifitas

Berdasarkan hal tersebut dilakukan penelitian untuk mengetahui pengaruh false mounting dengan produksi semen pejantan sapi Limousin dan Simmental di lapangan saat proses penampungan semen. Jumlah false mounting yang diamati dengan menghitung banyaknya pengekangan saat seekor pejantan menunggangi teaser tanpa dilakukan penampungan semen pada ejakulasi pertama (Rahmawati et al., 2015).

\section{MATERI DAN METODE PENELITIAN}

Penelitian ini dilaksanakan di Balai Inseminasi Buatan Lembang, Bandung, Provinsi Jawa Barat berlangsung pada tanggal 18 Desember 2017 sampai dengan 5 Januari 2018. Materi penelitian yang digunakan dalam penelitian ini adalah sapi Limousin dan Simmental berumur 59 tahun sebanyak 110 ekor yang terdiri dari 55 ekor Sapi Limousin dan 55 ekor sapi Simmental. Peralatan yang digunakan antara lain vagina buatan, dummy cow kandang jepit stop watch, spektrometer, air hangat, alat penyemprot prepitium, spatula, 
tabung, penampung berskala untuk meningkatkan kualitas semen. Variabel yang di amati adalah Volume semen, $\mathrm{pH}$ Semen, Gerakan Massa sperma, Motilitas spermatozoa, dan Kosentrasi spermatozoa. (Dewi et al, 2012).

Penelitian ini menggunakan metode pengamatan secara langsung di Balai Inseminasi Buatan Lembang Bandung Jawa Barat. Pengambilan data dilakukan setiap jam kerja (Senin - Jumat) Jam 07:00 - 11:00. Data yang diambil adalah berapa kali false mounting sampai dengan proses penampungan semen selesai dan dilanjutkan dengan pengujian secara makroskopis dan mikroskopis yaitu, volume semen, $\mathrm{pH}$ semen, gerakan massa semen, mortilitas spermatozoa, dan kosentrasi spermatozoa di labolatorium bertujuan untuk mendapatkan bibit unggul yang baik serta berkualitas (Dewi et al., 2012).
Data dianalisa secara deskriptif dengan cara menghitung standart devisiasi, koefisien dan korelasi uji $\mathrm{T}$ banding $t$-test menurut (Steel dan Torrie, 1993).

\section{HASIL DAN PEMBAHASAN}

\section{Pengaruh False Mounting Terhadap Rata- Rata Volume Semen Sapi Limousin dan Simmental}

Hasil penelitian pengaruh false mounting terhadap rata- rata volume semen sapi Limousin dan Simmental, seperti terlihat pada Tabel 1. Hasil penelitian pengaruh false mounting terhadap volume semen menunjukan bahwa secara nominal perlakuan False Mounting empat kali pada sapi Limousin dan Simmental menghasilkan volume tertinggi di bandingkan dengan yang lain, namun tidak berbeda nyata pada Limousin. Sedangkan pada false mounting 3 pada sapi Simmental

Tabel 1. Pengaruh False Mounting Terhadap Rata- Rata Volume (mL) Semen Sapi Limousindan Simmental

\begin{tabular}{ccccc}
\hline \multirow{2}{*}{ False Mounting (Kali) } & Sapi Limousin & Sapi Simmental & T hitung & T tabel \\
& & & & \\
\hline 3 & 7,70 & 8,15 & 0,04 & 0,01 \\
4 & 7,47 & 8,86 & 0,41 & 0,01 \\
5 & 7,41 & 6,56 & 0,30 & 0,01 \\
\hline
\end{tabular}


secara nominal menunjukan hasil terendah volume semen tetapi tidak berbeda nyata di bandingkan pada sapi Limousin.

Hertanti et al. (2012) menyatakan bahwa jumlah volume semen yang dihasilkan oleh sapi pejantan sebanyak $8 \mathrm{ml}$ dengan kisaran 2-15 ml. Volume semen di samping dipengaruhi oleh bangsa ternak, juga dipengaruhi oleh umur dan bobot badan serta juga dipengaruhi oleh keadaan dan jalannya proses reproduksi sapi jantan (Rokhana, 2008). Volume yang baik diproduksi oleh sapi potong dengan rata-rata $8,6 \pm 1,6 \mathrm{~mL}$ sedangkan pada sapi perah volume semen yang dihasilkan berkisar 5-8 $\mathrm{mL}$ (Rokhana 2008).

Perbedaan volume semen pada setiap ternak, diduga disebabkan oleh perbedaan umur, pengaruh invidu, berat badan, kondisi dan bangsa ternak seperti dilaporkan Aerens (2012), melakukan false mounting pada sapi pejantan selama beberapa kali dan atau dengan mendekatkan pejantan secara intensif selama 5 sampai 10 menit pada ternak betina massa birahi merupakan cara yang efektif untuk dapat menaikkan jumlah volume semen yang dihasilkan di bandingkan dengan tanpa adanya false mounting atau menaiki.

\section{Pengaruh False Mounting terhadap Rata- Rata pH Semen Sapi Limousin dan Simmental}

Hasil penelitian pengaruh False Mounting terhadap rata- rata $\mathrm{pH}$ semen sapi Limousin dan Simmental, seperti terlihat pada Tabel 2. Hasil analisis ragam menunjukkan bahwa tidak terdapat perbedaan yang nyata $(\mathrm{P}>0,01)$ antara, $\mathrm{pH}$ semen sapi Simmental dan sapi Limousin. Menurut Sundari (2013). pH semen normal sapi adalah 6,5-6,6 dengan rata-rata 6,75. Hasil Pengukuran yang dilakukan oleh Rahmawati et al. (2015) bahwa sapi Limousin dan sapi Eropah memiliki nilai pH semen sebesar 6,0 - 7,0. Selanjutnya dikatakan bahwa pH semen segarnya berkisar $6,2-6,8$. Derajat keasaman $(\mathrm{pH})$ pada sperma

Tabel 2. Pengaruh False Mounting Terhadap Rata- Rata pH Semen Sapi Limousin dan Simmental

\begin{tabular}{cllll} 
False Mounting (Kali) & Sapi Limousin & Sapi Simmental & T hitung & T tabel \\
& & & & \\
\hline 3 & 6,64 & 6,66 & 0,01 & 0,01 \\
4 & 6,62 & 6,68 & 0,07 & 0,01 \\
5 & 6,64 & 6,65 & 0,01 & 0,01 \\
\hline
\end{tabular}


untuk kedua bangsa sapi adalah 6,49 - 6,54 selanjutnya disampaikan bahwa derajat $\mathrm{pH}$ yang diperoleh dalam penelitian ini berbeda dengan Feradis (2010) yang menyatakan bahwa $\mathrm{pH}$ semen segar yang berkualitas baik adalah 6,7-6,8. Menurut Butar Butar (2009) $\mathrm{pH}$ semen segar adalah 6,4-7,8. Namun Feradis (2012) mengatakan bahwa setiap bangsa sapi mempunyai nilai $\mathrm{pH}$ semen segar yang berbeda-beda. Jadi $\mathrm{pH}$ semen segar sapi Bali yang digunakan sebagai bahan penelitian dapat dikatakan normal. Ketika di lihat dari Tabel 2, untuk $\mathrm{pH}$ semen sapi antara Limousin dan Simmental dan juga ternak sapi yang lain sama tidak ada perbedaannnya.

\section{Pengaruh False Mounting Terhadap Rata- Rata Gerakan Massa Semen Sapi Limousin Dan Simmental}

Hasil penelitian pengaruh false mounting terhadap rata- rata gerakan massa semen sapi Limousin dan Simmental, seperti terlihat pada Tabel 3. Hasil penelitian untuk rata-rata pada gerakan massa semen yang dihasilkan dari sapi Limousin pada false mounting ke lima lebih singkat dari pada sapi Simmental. Faradis (2010) menyatakan bahwa gerakan massa semen sapi adalah 1,94 $\pm 0,14$. Pada umumnya yang terbaik adalah pergerakan pada sapi pejantan Limousin dan Simmental Brahman. Hertanti (2012) juga menyatakan bahwa ada tiga gerakan massa spermatozoa, gerakan progresif, gerakan berputar, dan gerakan di tempat. Ada dua tipe gerakan terakhir disebabkan oleh gerak ayun-ayun ekor yang abnormal dan ditambahkan bahwa gerakan kurang dari $50 \%$ akan menghasilkan angka konsepsi yang lebih rendah. Pada spermatozoa sapi kisaran normal gerakan massa adalah ++ sampai dengan Gerakan massa atau daya gerak spermatozoa pada lima kali

Tabel 3. Pengaruh False Mounting Terhadap Rata- Rata Gerakan Massa Semen Sapi Limousin Simmental

False Mounting (Kali) Sapi Limousin Sapi Simmental Thitung T tabel

\begin{tabular}{lllll}
\hline 3 & 1,87 & 1,82 & 0,02 & 0,01 \\
4 & 1,9 & 1,95 & 0,02 & 0,01 \\
5 & 1,75 & 1,83 & 0,71 & 0,01 \\
\hline
\end{tabular}


penampungan rata-rata berkisar $6,8 \pm 8,37$ dan persentase hidupnya $5,8 \pm 8,37 \%$ nilai ini termasuk kisaran yang baik penilaian spermatozoa yang aktif yang bergerak atau hidup dilakukan pada suhu $37^{\circ} \mathrm{c}$ sampai $40^{\circ} \mathrm{c}$, untuk presentase sperma yang aktif tidak harus lebih besar dari pada $70^{\circ} \mathrm{c}$. Sama dengan yang di ungkapkan oleh Melita el al. (2014) bahwa untuk memperoleh hasil yang lebih tepat sebaiknya semen diperiksa pada suhu $37^{\circ}$ sampai $40^{\circ} \mathrm{C}$ dengan menempatkan gelas objek di atas suatu meja panas atau menggunakan mikroskop yang di panaskan secara Elektrik (Parasara 2015).

\section{Pengaruh False Mounting Terhadap Rata-Rata Motilitas Spermatozoa Sapi Limousin Dan Simmental (\%)}

Hasil penelitian pengaruh false mounting terhadap rata- rata motilitas sermatozoa sapi Limousin dan Simmental, seperti terlihat pada Tabel 4. Hasil penelitian pengaruh pada spermatozoa pada semen sapi Limousin dan Simmental secara nominal menunjukan nilai tertinggi pada false mounting ke 3 dibandingkan dengan ke 4 dan ke 5. Pada sapi Limousin jumlah motilitas spermatozoa pada semen sapi Limousin adalah $70 \%$ dan pada semen sapi Simmental 67,60\%. Dalam hal ini false mounting ke 3 adalah yang terbaik seperti yang di nyatakan oleh Prasetyo,et al (2013 ), bahwa hidup spermatozoa semen sapi nilainya harus lebih unggul dari $50 \%$. Motilitas spermatozoa menurut Prasetyo, et al. (2013) nilai mortilitas spermatozoa semen segar sapi Simmental adalah $80,16 \pm 7,80 \%$, nilai ini lebih tinggi $(\mathrm{P}<0,05)$ dibandingkan dengan Limousin, dan FH masing-masing hanya 75,31 $\pm 6,47$ dan $73,29 \pm 5,01 \%$. Meskipun demikian nilai motilitas spermatozoa dari ketiga breed tersebut termasuk normal. Karena menurut Prasetyo, et al. (2013) nilai motilitas spermatozoa sapi berkisar antara $70-80 \%$.

Tabel 4. Pengaruh False Mounting Terhadap Rata- Rata Motilitas Spermatozoa Sapi Limousin dan Simmental

False mounting (kali) Sapi Limousin $\quad$ Sapi Simmental $\quad$ Thitung $\quad \mathrm{T}$ tabel

\begin{tabular}{lllll}
\hline 3 & 70,00 & 67,60 & 10,63 & 0,01 \\
4 & 70 & 67 & 25,53 & 0,01 \\
5 & 66 & 68 & 0,22 & 0,01 \\
\hline
\end{tabular}


Banyak faktor yang mempengaruhi perbedaan nilai motilitas spermatozoa di antaranya umur, bangsa sapi, kematangan spermatozoa, dan kualitas plasma spermatozoa. Hal ini sesuai dengan penelitian Arifiantini et al. (2005) telah menyatakan bahwa umur tidak memberikan pengaruh terhadapmot ilitas massa semen sapi Simmental. Hasil Pemeriksaan rata- rata motilitas massa yang di hasilkan sapi Simmental pada umur yang berbeda (Nursyam, 2007).

\section{Pengaruh False Mounting Terhadap Rata-Rata Kosentrasi Spermatozoa Sapi Limousin dan Simmental}

Hasil penelitian pengaruh false mounting terhadap rata- rata kosentrasi sapi Limousin dan Simmental, seperti terlihat pada Tabel 5. Hasil penelitian di Balai Inseminasi Buatan Lembang menunjukan rata - rata konsentrasi spermatozoa sapi
Limousin pada false mouting 3 kali dan 5 sangat berbeda nyata. Angka capaian pada rataan kisaran waktu yang di butuhkan untuk kosentrasi pada data di atas untuk false mounting 5 sapi Limousin dan Simmental hasil yang di ambil sangat singkat. Wahyudi et al. (2016), menyatakan bahwa pada angka-angka 1340 \pm 447 , $85 \times 10$ berada dalam kisaran normal, sesuai pada sapi FH. Menurut Melita et al. (2014) menyatakan bahwa konsentrasi spermatozoa adalah 600 - $1.500 \mathrm{juta} / \mathrm{mL}$ untuk rata-rata kosentrasi. Selanjutnya menurut Dewi et al. (2012) menyatakan bahwa konsentrasi sperma pada ternak jantan 1200 juta/mL dengan kisaran 4002000 juta/mL. Konsentrasi sperma kedua bangsa sapi Limousin dan Simmental hampir tidak berbeda nyata. ButarButar (2009) juga menyatakan bahwa konsentrasi spermatozoa yang sama dipengaruhi oleh spesies sama umur telah mencapai pubertas.

Tabel 5. Pengaruh False Mounting Terhadap Rata- Rata Kosentrasi Spermatozoa Sapi Limousin Dan Simmental

\begin{tabular}{cllll} 
False Mounting (Kali) & Sapi Limousin & Sapi Simmental & T hitung & T tabel \\
& & & & \\
\hline 3 & 1041,67 & 108,70 & 0,06 & 0,01 \\
4 & 1061,15 & 1468,20 & 0,40 & 0,01 \\
5 & 1026,00 & 844,08 & 23,09 & 0,01 \\
\hline
\end{tabular}


Konsentrasi spermatozoa akan mengikuti perkembangan seksual dan kedewasaan, kualitas pakan yang diberikan, kesehatan alat reproduksi, besar testis, umur dan frekuensi ejakulasi pejantan. Ada ke cenderungan variasi sifat pada individu pada sapi pejantan Limousin dan Simmental (ButarButar et al 2009).

Efi (2008) menyatakan bahwa umur mempengaruhi konsentrasi spermatozoa diamati hasil pengamatannya menunjukkan bahwa konsentrasi spermatozoa semen segar yang diperoleh adalah 1561,87 - 1899,3 juta/mL. Kons entrasi spermatozoa ini sangat tinggi, mengingat bahwa konsentrasi spermatozoa pada sapi jantan dewasa berkisar $800-1200 \mathrm{juta} / \mathrm{ml}$ spermatozoa (Aerens, 2012). Sapi pejantan Limousin dan Simmetal Di Inseminasi Buatan Lembang nilai kosentrasi sperma terhadap kualitas semen Adhyata et al. (2012) yang menyatakan bahwa warna memiliki hubungan erat dengan konsentrasi spermatozoa, apabila konsentrasi semen tinggi maka warna pada bangsa sapi Brahman, Limousin dan Simmental. semen semakin keruh, karena individu, konsentrasi, viabilitas, maupun abnormalitas spermatozoa sapi.

\section{KESIMPULAN}

False Mounting yang di lakukan pada ternak sapi pejantan Limousin dan Simmental saat penampungan semen di Balai Inseminasi Buatan Lembang Jawa Barat berpengaruh pada kualitas semen baik secara makroskopis maupun secara mikroskopis.

\section{DAFTAR PUSTAKA}

Adhyata, M., I. Nurul dan Nuryadi. 2012. Pengaruh bobot badan terhadap kualitas dan kuantitas semen sapi simmental. Journal Ternak Tropika 14 (2) :53-62.

Aerens, C. D., M.N. Ihsan dan Isnaini. 2012. Perbedaan Kuantitatif Semen Segar Pada Berbagai Sapi Potong Malang.

Arifiantini, R.I., T.L. Yusuf dan D.Yanti. 2005. Kaji banding kualitas semen beku sapi friesian holstein. menggunakan pengencer dari berbagai Balai Inseminasi Buatan Di Indonesia. Journal. Animal Production 7 (3): 168176.

Butarbutar, E. 2009. Efektifitas Frekuensi Exercise Terhadap Peningkatan Kualitas Semen Sapi Simmental. Skripsi. 
Fakultas Pertanian, Universitas Sumatra Utara. Medan.

Dewi, S.A., Y.S. Ondho, dan E. Kurnianto. 2012. Kualitas semen berdasarkan umur pada sapi jawa. Animal Agriculture Journal 1(2): 126-133.

Efi, R. 2008. Hubungan antara jumlah false mounting dengan produksi semen pejantan Sapi Madura. Jurnal Cendekia. 3743.

Feradis. 2010. Bioteknologi Reproduksi Ternak. Alfabeta, Bandung.

Hartanti, D., E,T. Setiatin, dan Sutopo. 2012. Perbandingan penggunaan pengencer semen sitrat kuning telur terhadap persentase daya hidup spermatozoa Sapi Jawa Brebes. Animal Agri. Journal 1(1) :3342.

Melita, D., Dasrul. dan M. Adam. 2014. Pengaruh umur pejantan dan frekuensi ejakulasi terhadap kualitas spermatozoa Sapi Aceh. Jurnal Medika Veterenaria 8(1):15-19.

Nursyam, 2007. Perkembangan Iptek Bidang Reproduksi Ternak Untuk Meningkatkan Produktivitas Ternak. Http//: www.unlam.ac.id./Journal//Pdf File. Diakses Pada Tanggal 22 November 2018.
Parasara, I.G.N.A.M., N.L.G Sumardani, dan I.G. Suranjaya. 2015. Korelasi ukuran testis terhadap produksi dan kualitas semen cair babi landrace dalam rangkaian inseminasi buatan. Jurnal Peternakan Tropika 3(1): 93 - 104.

Prasetyo, A. A., R.T. Taswin dan M.S. Dadang. 2013. Kualitas Semen Segar Sapi Simmental Yang Dikoleksi Dengan Interval Yang Berbeda Di Balai Inseminasi Buatan Lembang. Jurnal Ilmiah Peternakan. 1(3): 907-913.

Rahmawati, M.A., T. Susilawati dan M.N. Ihsan. 2015. Kualitas semen dan produksi semen beku pada sapi dan bulan penampungan yang berbeda. Jurnal. Ilmu-Ilmu Peternakan 25(3): 25- 36.

Rokhana, E. 2008. Hubungan Antara Jumlah False Mounting Dengan Produksi Semen Pejantan Sapi Madura. Issn: 1693-6094.

Sundari, Triana Winda, Taswin Rahman Tagama, Dan Maidaswar. 2013. Korelasi kadar $\mathrm{pH}$ semen segar dengan kualitas semen sapi limousin Di Balai Inseminasi Buatan Lembang. Journal. Ilmiah Peternakan 1(3): 1043 - 1049

Suryadi, U., I. Irda, dan R.T. Hertamawati, 2008. Pengaruh timbal balik frekuensi dan 
lama pengekangan "False Mount" terhadap kualitas Sperma Domba Ekor Gemuk. Media Kedokteran Hewan 17(3).
Wahyudi, F, E, T., Susilawati dan N. Isnain. 2016. Pergantian bovine albumen pada CEP-2 dengan serum dara sapi limousin dan simental pada suhu penyimpanan $2-5^{\circ} \mathrm{C}$. J. Ternak Tropika 17(2):8 -15. 